\title{
GC-MS profiling and assessment of antioxidant, antibacterial, and anticancer properties of extracts of Annona squamosa L. leaves
}

Rawan Al-Nemari ${ }^{1}$, Abdulrahman Al-Senaidy ${ }^{1}$, Abdelhabib Semlali ${ }^{2}$, Mohammad Ismael ${ }^{1}$, Ahmed Yacine Badjah-Hadj-Ahmed ${ }^{3}$ and Abir Ben Bacha ${ }^{4,5^{*}}$ (D)

\begin{abstract}
Background: The research and application of plants in food supplements and drugs have attracted great interest. This study aimed to examine the efficiency of several solvents for the extraction of the main compounds from Annona squamosa leaves and to evaluate the antioxidant, antibacterial, and anticancer activities of these extracts.

Methods: Gas chromatography-mass spectrometry was used to screen the bioactive compounds of $A$. squamosa methanolic extract. The free radical, hydrogen peroxide, and nitric oxide scavenging activities of the extracts were investigated. Furthermore, MTT, nuclear staining, LDH, and monolayer wound repair assays were performed to evaluate the potential anticancer activity of the extracts in colon cancer cells while the antibacterial activity was tested by using a well diffusion assay.

Results: A. squamosa leaves extracts were found to contain several bioactive compounds, of which the majority were sesquiterpenes $\left(\mathrm{C}_{15} \mathrm{H}_{24}\right)$. These extracts exhibited strong antioxidant activity and antibacterial potency against both gram-positive and gram-negative bacteria. Different $A$. squamosa leaves extracts displayed remarkable antiproliferative, cytotoxic, antimigration, and apoptotic activities in colon cancer cells.
\end{abstract}

Conclusions: A. squamosa leaves contain major bioactive compounds that inhibit the growth of several types of bacteria and colon cancer cell lines, which demonstrated their efficacy as an alternative source of antibiotics and for the development of novel drugs for colon cancer therapy.

Keywords: A. squamosa, Phytomedicine, Bioactive compounds, Antioxidants, Antibacterial, Apoptosis

\footnotetext{
* Correspondence: aalghanouchi@ksu.edu.sa

${ }^{4}$ Department of Biochemistry, College of Science, King Saud University,

Riyadh, Kingdom of Saudi Arabia

${ }^{5}$ Laboratory of Plant Biotechnology Applied to Crop Improvement, Faculty of

Science of Sfax, University of Sfax, Sfax, Tunisia

Full list of author information is available at the end of the article
}

(c) The Author(s). 2020 Open Access This article is licensed under a Creative Commons Attribution 4.0 International License, which permits use, sharing, adaptation, distribution and reproduction in any medium or format, as long as you give appropriate credit to the original author(s) and the source, provide a link to the Creative Commons licence, and indicate if changes were made. The images or other third party material in this article are included in the article's Creative Commons licence, unless indicated otherwise in a credit line to the material. If material is not included in the article's Creative Commons licence and your intended use is not permitted by statutory regulation or exceeds the permitted use, you will need to obtain permission directly from the copyright holder. To view a copy of this licence, visit http://creativecommons.org/licenses/by/4.0/ The Creative Commons Public Domain Dedication waiver (http://creativecommons.org/publicdomain/zero/1.0/) applies to the data made available in this article, unless otherwise stated in a credit line to the data. 


\section{Background}

One of the most studied topics over the last two decades among biologists worldwide is oxidative stress as it is commonly associated with several diseases including autoimmune and inflammatory diseases $[1,2]$. Oxidative stress is a signal that reflects the overwhelming production of reactive oxygen and nitrogen species (RONS) that exceeds the antioxidant capacity within a cell. Prolonged oxidative stress can damage cellular building blocks, disrupt cellular signaling, and induce the release of inflammatory signaling molecules $[3,4]$. Indeed, RONS-mediated oxidative stress has been found in the initiation, development, and progression of cancer. Cancer is the leading cause of death in economically developed countries and the second leading cause of death in developing countries, making it a serious global problem [5,6]. Despite the availability of effective treatment options for the early stages of cancer, such as chemotherapy, surgery, radiotherapy, and hormone therapy, their use is costly and remains limited in the later stages of cancer. They can cause serious side effects in the patient and pose a real problem for public health $[7,8]$. In addition, one of the most critical aspects of cancer therapy that faces scientists and doctors is resistance to treatment, which can occur after prolonged treatment with the same drug, reducing the level of RONS and inducing resistance to apoptosis [2, 3]. Currently, researchers investigate second-line treatments, which could be natural products, for use in addition to chemotherapy or even as chemopreventative agents [9]. Recent statistics have shown that approximately $85 \%$ of people use plant extracts to treat various diseases in the country based on their healthcare needs [10]. Many studies have reported the critical roles of natural plant extracts in the development of new anticancer drugs. They have emerged as potential compounds for use as adjuvant or complementary anti-cancer drugs with fewer side effects [11].

The antibiotic revolution has decreased the spread and severity of many minor diseases. However, due to the increasing number of microbial infections and the uncontrolled use of antibiotics, antibiotic resistance becomes a global public health threat. In 2012, the World Health Organization called for urgent corrective action, including the identification of new therapeutic agents, resulting in the increased frequency of microbial resistance and its association with serious infectious diseases [12]. Traditional herbal medicines are reported to possess antimicrobial effects. Thus, researchers have become more interested in the antimicrobial activity of natural products [13-15]. Through the use of natural antimicrobial compounds, the opportunity for bacteria to acquire resistance is minimized, and bacteria can be targeted via several mechanisms [16].

Annona squamosa L. (A. squamosa) is a small group of edible fruits belonging to the Annonaceae family and Annona $L$. genus, commonly known as custard apple. It is a native species found in tropical and subtropical regions worldwide. Traditionally, all parts of $A$. squamosa are used to treat different diseases in many countries, including India and China. For example, the seed powder is used to eliminate head lice, the leaves are used as a poultice to heal boils and ulcers, and the part of the fruit are used a sedative for the heart, to alleviate vomiting, and to treat cancer $[17,18]$. In recent decades, several studies have reported that different parts of $A$. squamosa contain several bioactive compounds, such as acetogenin, alkaloids, steroids, terpenoids, saponins, and phenolics, which exert various biological activities $[18,19]$. However, fewer studies were conducted on A. squamosa $\mathrm{L}$. than other species within the same genus; many fewer studies focused on the leaves than other parts, and these mostly explored the antioxidant and antibacterial activities. This study aimed to investigate the constituent bioactive chemicals and the antioxidant, anticancer, and antibacterial activities of three different extracts of $A$. squamosa leaves.

\section{Methods \\ Plant material}

A. squamosa L. leaves were collected from a local plant nursery in Ta'if, Saudi Arabia, in December 2016. The identification and authentication was performed by Ibrahim Al-Dakhil, an agronomist, then confirmed by the Department of Botany and Microbiology, College of Science, King Saud University. A voucher specimen (KSU-No. 12068) was deposited at the Herbarium of the college of science, KSU. The plant leaves were then washed with running tap water until clean, shade-dried for 7 days, crushed into small pieces, and powdered by using an electric blender. The obtained powder was stored at $-20^{\circ} \mathrm{C}$ until subjected to further extraction procedures.

\section{Extraction of plant material}

Three different extracts were prepared from dried $A$. squamosa leaves powder by using three solvents of different polarity: methanol, acetone and water. The methanol and acetone extracts were prepared by macerating the dried powder with methanol or acetone (1:10 $\mathrm{w} / \mathrm{v})$ for $48 \mathrm{~h}$. The extracts were filtered using Whatman No. 40 filter paper (Whatman ${ }^{\circ}$ Schleicher \& Schuell, UK) and concentrated under a fume hood via evaporation at $18-21{ }^{\circ} \mathrm{C}$ (room temperature). For the aqueous extract, the dried powder was macerated with distilled water $(1: 10 \mathrm{w} / \mathrm{v})$ for $48 \mathrm{~h}$. After centrifugation at 10000 rpm for $10 \mathrm{~min}$, the sediment was discarded, and the resulting aqueous fraction was filtered through filter paper and lyophilized by using FreeZone 4.5 Liter Benchtop Freeze Dry System (Labconco, USA). Finally, A. squamosa extracts were weighed to determine the extraction yields $(\% \mathrm{w} / \mathrm{w})$ and stored at $-20{ }^{\circ} \mathrm{C}$ in lightprotected sterile containers for further experiments. For 
use, each extract was dissolved in the initial extraction solvent.

\section{Total phenolic content}

The total phenolic content (TPC) of A. squamosa leaves extracts was estimated spectrophotometrically using the Folin-Ciocalteau method [20]. For each sample, $0.3 \mathrm{~mL}$ $(80 \mu \mathrm{g} / \mathrm{mL})$ was mixed with Folin-Ciocalteau reagent $(1.5 \mathrm{~mL}$; diluted 10 times) and sodium carbonate $(1.2$ $\mathrm{mL} ; 7.5 \% \mathrm{w} / \mathrm{v})$. After incubation of the mixture for 30 min at room temperature, the absorbance was measured at $765 \mathrm{~nm}$. The total phenolic content was expressed as gallic acid equivalents (GAE) in mg per $g$ of dry material (mg GAE/g), using a standard calibration curve.

\section{Total flavonoid content}

The total flavonoid content (TFC) of A. squamosa extracts was determined according to Loganayaki et al. [21]. First, an $0.25 \mathrm{~mL}$ aliquot of the extract $(80 \mu \mathrm{g} / \mathrm{mL})$ was mixed with distilled water $(1 \mathrm{~mL})$, followed by the addition of $5 \% \mathrm{NaNO}_{2}$ solution $(0.075 \mathrm{~mL})$. After $5 \mathrm{~min}$, $10 \% \mathrm{AlCl}_{3}$ solution $(0.15 \mathrm{~mL})$ was added to the mixture, which was then incubated for 6 min. Finally, $4 \% \mathrm{NaOH}$ $(0.5 \mathrm{~mL})$ was added and the volume was adjusted to 5 $\mathrm{mL}$ with distilled water. After incubation for $15 \mathrm{~min}$, the absorbance was determined at $415 \mathrm{~nm}$. The total flavonoid content was expressed as quercetin equivalents in $\mathrm{mg}$ per $\mathrm{g}$ of dry material (mg quercetin/g), using a standard calibration curve.

\section{Gas chromatography coupled with mass spectrometry}

The chemical composition of the methanolic extract of $A$. squamosa leaves was investigated by using gas chromatography coupled with mass spectrometry (GC-MS). GC-MS analysis was performed using a Thermo Trace GC Ultra gas chromatograph coupled with a TSQ Quantum mass spectrometer (triple quadrupole). The mass detector was operated at $70 \mathrm{eV}$ ionization energy, $0.132 \mathrm{~s} / \mathrm{scan}$ in full scan mode, over the mass range of $40-500 \mathrm{Da}$. The chromatograph was equipped with a Thermo TR-5MS fused silica capillary column (length, $30 \mathrm{~m}$; i.d., $0.25 \mathrm{~mm}$; and film thickness, $0.25 \mu \mathrm{m})$. The stationary phase was $5 \%$ phenyl polysilphenylene-siloxane. The following oven temperature was increased from $40^{\circ} \mathrm{C}$ to $300^{\circ} \mathrm{C}$ between 0 and $10 \mathrm{~min}$ at a rate of $6^{\circ} \mathrm{C} / \mathrm{min}$, with the injector temperature of $250{ }^{\circ} \mathrm{C}$. Helium was used as the carrier gas, with a flow rate of $1 \mathrm{~mL} / \mathrm{min}$ and a split flow of $25 \mathrm{~mL} / \mathrm{min}$, which corresponded to a split ratio of 25 . The transfer line temperature was set at $250^{\circ} \mathrm{C}$. The compounds were identified through the comparison of their mass spectra with the reference mass spectra of several libraries, including Wiley Library 7n.1, the NIST (National Institute of Standards and Technology), and previously published literature data.

\section{Antioxidant activity}

\section{Free radical scavenging activity}

The antioxidant activity of $A$. squamosa extracts was measured in vitro on the basis of the scavenging activity of the 2,2-diphenyl-1-picrylhydrazyl (DPPH) free radical, as previously reported by Narasimhan et al. [22]. First, 0.1 $\mathrm{mM}$ DPPH $(1 \mathrm{~mL})$ was mixed with $1 \mathrm{~mL}$ of various concentrations of plant extracts $(10-100 \mu \mathrm{g} / \mathrm{mL})$. The corresponding blank samples were also prepared, along with a control containing distilled water instead of the extract. The reaction was conducted in triplicate using $\mathrm{L}$-ascorbic acid $(2-100 \mu \mathrm{g} / \mathrm{mL})$ for the standards. After incubation in the dark for $30 \mathrm{~min}$, the absorbance at $517 \mathrm{~nm}$ was measured. The percentage of DPPH radical scavenging activity was calculated from the following equation:

Scavenging activity $(\%)=($ absorbance of control - absorbance of sample $)$ /absorbance of control $\times 100$

\section{Hydrogen peroxide scavenging activity}

To measure the hydrogen peroxide $\left(\mathrm{H}_{2} \mathrm{O}_{2}\right)$ scavenging activity of $A$. squamosa extracts, the method of Ruch et al. [23] was used. Different concentrations $(0.1-1 \mathrm{mg} /$ $\mathrm{mL}$ ) of $0.1 \mathrm{~mL}$ of each extract were treated with $40 \mathrm{mM}$ $\mathrm{H}_{2} \mathrm{O}_{2}$ solution $(0.6 \mathrm{~mL})$ in phosphate buffer ( $\left.\mathrm{pH} 7.4\right)$. After $10 \mathrm{~min}$, the absorbance of $\mathrm{H}_{2} \mathrm{O}_{2}$ was measured at $230 \mathrm{~nm}$ against a blank solution of phosphate buffer. The control was prepared by using distilled water instead of the extract and $0.1-1 \mathrm{mg} / \mathrm{mL} \mathrm{L}$-ascorbic acid was used for the standards. The percentage of $\mathrm{H}_{2} \mathrm{O}_{2}$ radical scavenging activity was calculated from the following equation:

Scavenging activity $(\%)=($ absorbance of control - absorbance of sample $)$ /absorbance of control $\times 100$

\section{Nitric oxide scavenging activity}

The ability of $A$. squamosa extracts to scavenge nitric oxide (NO) was assessed by the method of Garratt et al. [24]. An aliquot of $0.5 \mathrm{~mL}$ of $10 \mathrm{mM}$ sodium nitroprusside (in phosphate buffer saline $\mathrm{pH}$ 7.4) was mixed with $1 \mathrm{~mL}$ of each extract $(10-100 \mu \mathrm{g} / \mathrm{mL})$. After incubation at $25^{\circ} \mathrm{C}$ for $180 \mathrm{~min}$, an equal volume of fresh Griess reagent was added. Griess reagent was prepared by mixing $1 \%$ sulfanilamide in $5 \%$ phosphoric acid and $0.1 \%$ naphthylethylene diamine dihydrochloride in distilled water. The corresponding blank sample, without sodium nitroprusside, and the control, containing phosphate buffer instead of extract, were also prepared, and gallic acid and L-ascorbic acid (10-100 $\mu \mathrm{g} / \mathrm{mL})$ were used for the standards. Finally, the absorbance at $546 \mathrm{~nm}$ was 
measured and the percentage of NO radical scavenging activity was calculated from the formula:

Scavenging activity $(\%)=($ absorbance of control - absorbance of sample) /absorbance of control $\times 100$

\section{Reducing power}

The reducing power of $A$. squamosa extracts was investigated by using slight modifications to the method of Oyaizu [25]. The extracts $(0.25-1 \mathrm{mg} / \mathrm{mL})$ were mixed with phosphate buffer $(2.5 \mathrm{~mL}, \mathrm{pH} 6.6)$ and $1 \%$ potassium ferricyanide $(2.5 \mathrm{~mL})$, and incubated at $50{ }^{\circ} \mathrm{C}$ for $20 \mathrm{~min}$. After the addition of $10 \%$ trichloroacetic acid $(2.5 \mathrm{~mL})$, the mixture was centrifuged at $650 \mathrm{rpm}$ for 10 min. Subsequently, the upper layer of the mixture $(2.5$ $\mathrm{mL}$ ) was mixed with an equal volume of distilled water and freshly prepared $0.1 \%$ ferric chloride $(0.5 \mathrm{~mL})$. Finally, the absorbance was measured at $700 \mathrm{~nm}$; butylated hydroxytoluene (BHT) and L-ascorbic acid were used as the standards.

\section{Antiproliferative activity \\ Cell culture}

Colon cancer cell lines (Lovo and HCT-116) were obtained from American Type Culture Collection (ATCC, USA) and cultured in Dulbecco's Modified Eagle's (DMEM) medium (Gibco, USA) supplemented with 10\% fetal bovine serum (FBS; SIGMA, USA) and $2 \times 10-3 \mathrm{v} / \mathrm{v}$ penicillin-streptomycin (composed of $31 \mathrm{~g} / \mathrm{L}$ penicillin, $50 \mathrm{~g} / \mathrm{L}$ streptomycin) in a humidified atmosphere with $5 \% \mathrm{CO} 2$ at $37^{\circ} \mathrm{C}$. During cell culture, the medium was replaced every 2 days until $80 \%$ confluency was reached.

\section{Cell viability assay}

The anti-proliferative activity of the extracts was determined by using the 3-(4.5-dimethythiazol-2-yl)-2,5diphenyl tetrazolium bromide (MTT) assay [26]. All extracts were dissolved in DMSO and subsequently diluted in culture medium. Briefly, the cells were seeded in 6 -well plates $(4 \times 105$ cells/well $)$ and treated with various concentrations of the leaves extract $(1 \mu \mathrm{g} / \mathrm{mL}$, $10 \mu \mathrm{g} / \mathrm{mL}$, and $100 \mu \mathrm{g} / \mathrm{mL}$ ) for $24 \mathrm{H}$. medium was removed, the cells were washed twice with PBS and incubated with $100 \mu \mathrm{L}$ MTT ( $5 \mathrm{mg} / \mathrm{mL}$; Sigma, USA) for $4 \mathrm{~h}$. Subsequently, the supernatant was removed, and $0.04 \mathrm{~N}$ $\mathrm{HCl}$ in isopropanol $(500 \mu \mathrm{L})$ was added to each well. Finally, $100 \mu \mathrm{L}$ of the reaction mixture was transferred to a 96-well plate and the maximum absorbance at $550 \mathrm{~nm}$ was detected by using an ELISA plate reader (X-Mark Microplate Spectrophotometer, Bio-Rad, USA). The experiment was conducted in triplicate. The percentage of cell viability was calculated from the following formula:
Cell viability $(\%)=($ absorbance of test sample/absorbance of negative control) $\times 100$.

\section{Nuclear staining}

The morphology of treated cells was assessed by using a Hoechst 33342 staining assay (H42) as previously described by Semlali et al. [26]. The cells were seeded in 6-well tissue culture plates $(3 \times 105$ cells/well). After overnight incubation, the medium was removed, replaced with media, and the cells were treated with different concentrations of extracts and incubated for $24 \mathrm{~h}$. The supernatant was then removed, the cells were washed twice with PBS and cold methanol was used to fix the cells for $15 \mathrm{~min}$. These cells were washed twice with PBS and subsequently stained with $2 \mu \mathrm{g} / \mathrm{mL}$ Hoechst 33342 (Thermo Fisher Scientific, DE) for $15 \mathrm{~min}$ in the dark. The stained nuclei were washed twice with PBS and observed and photographed under Leica DM2500 \& DM2500 LED optical microscopes (LEICA Microsystems, DE).

\section{Cytotoxicity assay}

The cytotoxicity of A. squamosa extracts on Lovo and HCT-116 cell lines was quantitatively assessed through the measurement of lactate dehydrogenase (LDH). The cells were cultured for $24 \mathrm{~h}$ in 6 -well plates $(4 \times 105$ cells/well). After overnight growth, the culture medium was removed and replaced by $1 \mathrm{~mL}$ of culture medium. Then, the cells were treated with various concentrations of the leaves extract $(1 \mu \mathrm{g} / \mathrm{mL}, 10 \mu \mathrm{g} / \mathrm{mL}$, and $100 \mu \mathrm{g} /$ $\mathrm{mL}$ ) for $24 \mathrm{~h}$. To estimate LDH activity, $10 \mu \mathrm{L}$ of the culture supernatant was transferred to a new 96-well plate and the enzyme reaction was conducted in accordance with the manufacturer's instructions (LDH cytotoxicity colorimetric assay kit II, BioVision, USA). The cytotoxicity was calculated as a percentage by using the following formula:

Cytotoxicity $(\%)=($ test sample - negative control $) /$ (positive control - negative control) $\times 100$.

\section{Monolayer wound repair assay}

Colon cancer cell lines were grown in 6-well plates. Wounds were made in a confluent monolayer of each well by using a $10 \mu \mathrm{L}$ pipette tip. The cells were then treated with $50 \mu \mathrm{g} / \mathrm{mL}$ of the methanolic, acetonic, or aqueous extract and the wound closure was compared with that of untreated cells at 0,6 , and $24 \mathrm{~h}$ after wounding [27]. Digital photographs were captured with a LEICA DFC450 C digital camera (LEICA Microsystems, $D E)$. The percentage of wound closure was calculated through the comparison of the wound areas before and after stimulation using the following formula:

Wound closure $(\%)=($ initial scratch size - size of the scratch after an identified culture period) / (initial scratch size) $\times 100$. 


\section{Antibacterial activity}

\section{Bacteria and growth conditions}

Based on their clinical and pharmacological importance, Bacillus subtilis (B. subtilis), Staphylococcus aureus (S. aureus), Enterococcus faecalis (E. faecalis), Escherichia coli (E. coli), Pseudomonas aeruginosa (P. aeruginosa), Klebsiella pneumoniae (K. pneumoniae), and Salmonella typhimurium (LT2) were selected for the evaluation of antibacterial activities of the A. squamosa leaves extracts. These bacterial strains were obtained from Botany and Microbiology Department, College of Science, King Saud University. The fresh culture of each microorganism was grown in Luria-Bertani media (Bio Basic, CAN), until McFarland standard 0.5 was reached. Subsequently, the suspensions were diluted with sterile $0.9 \%$ normal saline (1:100) to obtain 106 colonies forming unit $/ \mathrm{mL}$.

\section{Agar well diffusion assay}

The antibacterial activity of $A$. squamosa leaves extracts was assessed against different bacterial species by using an agar well diffusion assay following the method of Balouiri et al. [13]. The bacterial inoculum was uniformly spread by using a sterile cotton swab on a Mueller-Hinton agar plate (Becton Dickinson, USA). Then, a hole (diameter, 6 $\mathrm{mm}$ ) was punched aseptically with a sterile tip and $100 \mu \mathrm{L}$ of each extract solution $(50 \mathrm{mg} / \mathrm{mL}$ in dimethyl sulfoxide; DMSO; Sigma, USA) was used to fill the wells. Reference commercial discs $(30 \mu \mathrm{g}$ Tetracycline; OXOID) were also conducted, and $100 \mu \mathrm{L}$ DMSO, instead of extract, was used for the negative control. After incubation for $24 \mathrm{~h}$ at $37^{\circ} \mathrm{C}$ under aerobic conditions, the zone of inhibition of bacterial growth was measured in millimeters. Experiments were performed in duplicate.

\section{Statistical analysis}

Statistical analyses were computed by using SPSS software (Statistical Package for the Social Sciences; version 21 for Mac). The values were presented as the arithmetical mean \pm standard deviation $( \pm S D)$. The statistical significance of differences was evaluated by one-way analysis of variance (ANOVA) followed by Dunnett's multiple comparison test. $P \leq 0.05$ was considered to indicate statistical significance, whereas a value of $\leq 0.005$ was considered to indicate a highly significant statistically difference to the relevant control.

\section{Results \\ Determination of extraction yield, TPC, and TFC of $A$. squamosa leaves extracts}

The weight (percentage yield) of the obtained dried crude extracts was calculated with respect to the initial amount of the dried powder; the values are presented in Table 1. It was observed that the water extract was obtained in the highest yield, followed by the methanolic and acetonic extracts. The highest TPC was found in methanol extract, followed by the acetone and water extracts. While the TFC of the acetonic extract was four times higher than that of the methanolic extract $(7.1 \pm$ $0.9 \mathrm{mg}$ quercetin/g and $1.8 \pm 0.1 \mathrm{mg}$ quercetin/g, respectively); however, only trace amounts were present in the water extract $(0.1 \pm 0.05 \mathrm{mg}$ quercetin/g) (Table 1$)$.

\section{Identification and characterization of chemical compounds in $A$. squamosa leaves extracts}

The GC-MS profile of the methanolic extract of $A$. squamosa leaves is shown in Fig. 1. The main constituents identified in the extract are reported in Table 2. Most components were sesquiterpenic hydrocarbons, such as germacrene-D (22.01\%), trans-caryophyllene (12.12\%), bicyclogermacrene (2.80\%), $\alpha$-copaene $(2.12 \%)$, and humulene $(1.15 \%)$, as well as phytol (2.22\%) and squalene (1.3\%). Further investigation into the main constituents of the acetonic and aqueous extracts of $A$. squamosa leaves well be covered in the future.

\section{The antioxidant activity of $A$. squamosa extracts Free radical scavenging activity}

A. squamosa leaves extracts were tested for their ability to scavenge the DPPH radical, as DPPH is one of the few stable and commercially available organic nitrogen radicals [28]. As shown in Fig. 2-a, the studied extracts displayed dose-dependent DPPH scavenging activities in the following order: acetone extract > methanol extract $>$ water extract. Furthermore, the concentrations of

Table 1 Percentage extraction yields obtained from A. squamosa extracts, total phenolic and flavonoids content, and the $\mathrm{IC}_{50}$ values for $\mathrm{DPPH}, \mathrm{H}_{2} \mathrm{O}_{2}$, and $\mathrm{NO}$ scavenging activity

\begin{tabular}{|c|c|c|c|c|c|c|}
\hline \multirow{2}{*}{$\begin{array}{l}\text { A. squamosa } \\
\text { leaves } \\
\text { extracts }\end{array}$} & \multirow{2}{*}{$\begin{array}{l}\text { Extraction } \\
\text { yield } \\
(\% \mathrm{w} / \mathrm{w})\end{array}$} & \multirow{2}{*}{$\begin{array}{l}\text { Total } \\
\text { phenolic } \\
\text { content } \\
\text { (mg GAE/g) }\end{array}$} & \multirow{2}{*}{$\begin{array}{l}\text { Total } \\
\text { flavonoids } \\
\text { content } \\
\text { (mg quercetin/g) }\end{array}$} & \multicolumn{3}{|l|}{$\mathrm{IC}_{50}$} \\
\hline & & & & $\begin{array}{l}\mathrm{DPPH} \\
(\mu \mathrm{g} / \mathrm{ml})\end{array}$ & $\begin{array}{l}\mathrm{H}_{2} \mathrm{O}_{2} \\
(\mathrm{mg} / \mathrm{ml})\end{array}$ & $\begin{array}{l}\mathrm{NO} \\
(\mu \mathrm{g} / \mathrm{ml})\end{array}$ \\
\hline Methanol & $6.96 \pm 0.68$ & $282.1 \pm 11.2$ & $1.8 \pm 0.1$ & $51 \pm 1.6$ & $735 \pm 49.5$ & $12 \pm 4.2$ \\
\hline Acetone & $5.84 \pm 0.33$ & $256.3 \pm 12.5$ & $7.1 \pm 0.9$ & $33.9 \pm 4.8$ & $516.7 \pm 5.8$ & $44 \pm 5.7$ \\
\hline Water & $13.07 \pm 0.24$ & $16.9 \pm 0.4$ & $0.1 \pm 0.05$ & $98.3 \pm 0.4$ & $110 \pm 14.1$ & $81 \pm 1.4$ \\
\hline
\end{tabular}

The results are presented as mean \pm SD $(n=3)$ 

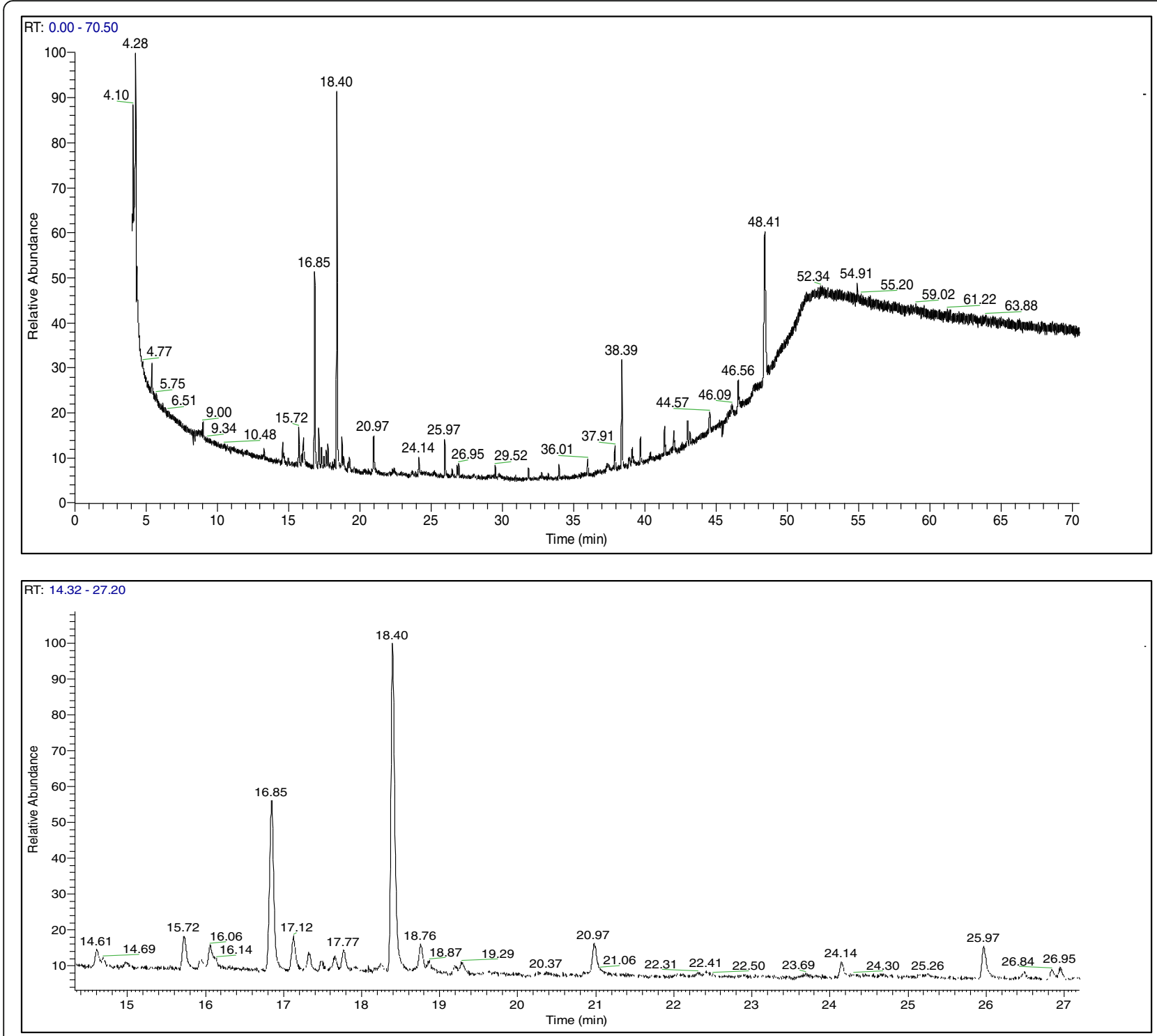

Fig. 1 Gas chromatography-mass spectrometry profile of methanolic extract of Annona squamosa leaves. RT: retention time

the extracts that were able to scavenge $50 \%$ of the $\mathrm{DPPH}$ radical $\left(\mathrm{IC}_{50}\right)$ were calculated and are presented in Table 1. The acetone extract had the lowest $\mathrm{IC}_{50}(33.9 \pm 4.8 \mu \mathrm{g} / \mathrm{mL})$, followed by methanol $\left(\mathrm{IC}_{50}=\right.$ $51 \pm 1.6 \mu \mathrm{g} / \mathrm{mL})$ and then water $\left(\mathrm{IC}_{50}=98.3 \pm 0.4 \mu \mathrm{g} / \mathrm{mL}\right)$ extracts.

\section{$\mathrm{H}_{2} \mathrm{O}_{2}$ scavenging activity}

The ability of $A$. squamosa extracts to scavenge $\mathrm{H}_{2} \mathrm{O}_{2}$ was investigated in relation to that of ascorbic acid; the results are shown in Fig. 2-b. Our findings demonstrated that the A. squamosa extracts exhibited dose-dependent scavenging of $\mathrm{H}_{2} \mathrm{O}_{2}$. The water extract exhibited the most efficient $\mathrm{H}_{2} \mathrm{O}_{2}$-radical scavenging ability, with an $\mathrm{IC}_{50}$ value of $110 \pm 14.1 \mu \mathrm{g} / \mathrm{mL}$ (vs. ascorbic acid,
$\left.\mathrm{IC}_{50}=55 \pm 7.1 \mu \mathrm{g} / \mathrm{ml}\right)$, followed by methanolic $\left(\mathrm{IC}_{50}=\right.$ $735 \pm 49.5 \mu \mathrm{g} / \mathrm{mL})$ and acetonic $\left(\mathrm{IC}_{50}=516 \pm 5.8 \mu \mathrm{g} / \mathrm{mL}\right)$ extracts (Table 1).

\section{NO scavenging activity}

The NO scavenging activity of $A$. squamosa extracts was determined by following the decrease in the absorbance at $546 \mathrm{~nm}$, as described by Boora et al. [29], and the results were presented as a percentage of scavenging activity in Fig. 2-c. All extracts possessed dose-dependent NO scavenging activity. The methanolic extract was found to be more efficient than the reference, ascorbic acid, with $\mathrm{IC}_{50}$ values of $12 \pm 4.2 \mu \mathrm{g} / \mathrm{mL}$ and $16.5 \pm 2.12 \mu \mathrm{g} / \mathrm{mL}$, respectively. The acetone and water extracts were less effective, 
Table 2 The major compounds identified in methanolic extracts of A. squamosa leaves; retention times (RT), classification, formula and molecular weight (Mw)

\begin{tabular}{|c|c|c|c|c|c|c|}
\hline No. & RT & Proposed compound & Class & Formula & $\mathrm{Mw}$ & $\%$ \\
\hline 1 & 14.60 & bicycloelemene & sesquiterpene & $\mathrm{C}_{15} \mathrm{H}_{24}$ & 204 & 1.28 \\
\hline 2 & 14.69 & d-elemene & sesquiterpene & $\mathrm{C}_{15} \mathrm{H}_{24}$ & 204 & 0.46 \\
\hline 3 & 15.72 & a-copaene & sesquiterpene & $\mathrm{C}_{15} \mathrm{H}_{24}$ & 204 & 2.12 \\
\hline 4 & 15.94 & $\beta$-bourbonene & sesquiterpene & $\mathrm{C}_{15} \mathrm{H}_{24}$ & 204 & 0.71 \\
\hline 5 & 16.85 & trans-caryophyllene & sesquiterpene & $\mathrm{C}_{15} \mathrm{H}_{24}$ & 204 & 12.12 \\
\hline 6 & 17.48 & a-amorphene & sesquiterpene & $\mathrm{C}_{15} \mathrm{H}_{24}$ & 204 & 0.60 \\
\hline 7 & 17.65 & $\gamma$-muurolene & sesquiterpene & $\mathrm{C}_{15} \mathrm{H}_{24}$ & 204 & 0.73 \\
\hline 8 & 17.77 & humulene & sesquiterpene & $\mathrm{C}_{15} \mathrm{H}_{24}$ & 204 & 1.15 \\
\hline 9 & 18.40 & germacrene-D & sesquiterpene & $\mathrm{C}_{15} \mathrm{H}_{24}$ & 204 & 22.01 \\
\hline 10 & 18.76 & bicyclogermacrene & sesquiterpene & $\mathrm{C}_{15} \mathrm{H}_{24}$ & 204 & 2.80 \\
\hline 11 & 25.97 & phytol & diterpene alcohol & $\mathrm{C}_{20} \mathrm{H}_{40} \mathrm{O}$ & 296 & 2.22 \\
\hline 12 & 42.05 & squalene & triterpene & $\mathrm{C}_{30} \mathrm{H}_{50}$ & 410 & 1.30 \\
\hline 13 & 48.41 & palmitone & ketone & $\mathrm{C}_{31} \mathrm{H}_{62} \mathrm{O}$ & 450 & 16.92 \\
\hline
\end{tabular}

with $\mathrm{IC}_{50}$ values of $44 \pm 5.7 \mu \mathrm{g} / \mathrm{mL}$ and $81 \pm 1.4 \mu \mathrm{g} / \mathrm{mL}$, respectively (Table 1).

\section{Reducing power of $A$. squamosa leaves extracts}

The reducing power of $A$. squamosa extracts was evaluated by the reduction of $\mathrm{Fe}^{3+}$ to $\mathrm{Fe}^{2+}$ and compared with ascorbic acid and BHT, as standard references. The data in Fig. 2-d demonstrate that reducing power increased as the concentration of the extract increased. At 0.75 $\mathrm{mg} / \mathrm{mL}$, the absorbance values of $A$. squamosa extracts were higher than the standards and followed the order: water extract $(0.984)>$ methanol extract $(0.975)>$ acetone extract $(0.95)>$ ascorbic acid (0.92) > BHT (0.91).

\section{The anticancer activity of $A$. squamosa extract on colon cancer cell lines}

The effect of A. squamosa extract on cell morphology and survival

The treatment of different colon cancer cell lines with $A$. squamosa leaves extracts did not induce noticeable changes
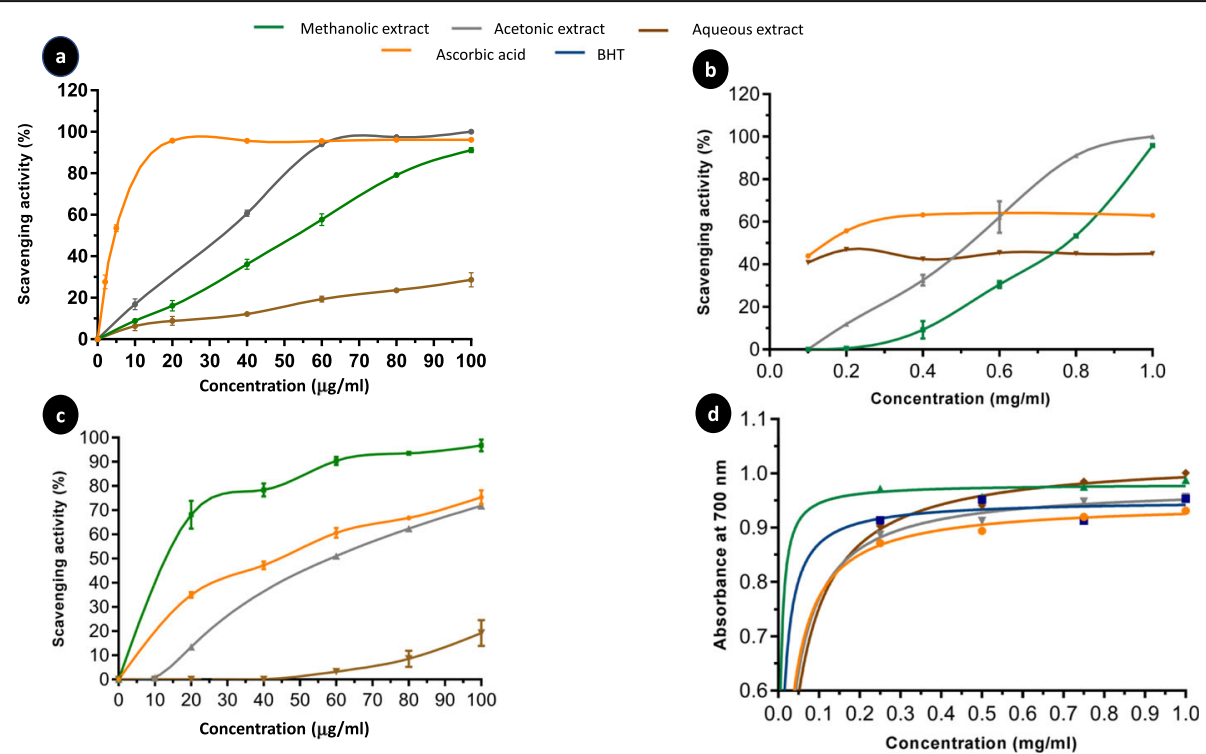

Fig. 2 The antioxidant activity of Annona squamosa leaves extracts. a The dose-dependent DPPH scavenging activity of leaves extracts relative to that of L-ascorbic acid. $\mathbf{b}$ The dose-dependent hydrogen peroxide scavenging activity of leaves extracts relative to that of L-ascorbic acid. $\mathbf{c}$ The dose-depended nitric oxide radical scavenging activity of leaves extracts. Gallic acid and L-ascorbic acid were used as standards. $\mathbf{d}$ The reducing power assay of different concentrations of leaves extract, L-ascorbic acid, and BHT. All results are presented as the mean \pm SD $(n=3)$ 
in cell morphology, but it affected the number of cells (Fig. 3). Therefore, the anti-proliferative activity of the extracts was evaluated using an MTT assay. The data in Fig. 4 demonstrate that the tested extracts (methanolic, acetonic, and aqueous) inhibited the proliferation of colon cancer cells in a dose-dependent manner. All extracts induced a highly significant decrease in Lovo cell viability at $100 \mu \mathrm{g} /$ $\mathrm{mL}$, with more than $85 \%$ inhibition (Fig. 4-a). Similarly, at the same concentration, the methanolic, acetonic, and aqueous extracts inhibited HCT-116 cell proliferation by 94, 91, and 58\%, respectively (Fig. 4-b). Furthermore, to confirm the antiproliferative activity of the A. squamosa extracts, nuclear staining was performed. The treatment of the cell lines with different concentrations of methanolic extract $(1,10$, and $100 \mu \mathrm{g} / \mathrm{mL})$ resulted in a marked dose-dependent decrease in the number of cells and notable damage to the nucleus (Fig. 4-c). A similar effect was observed after treatment acetone and water extracts (data not shown).

\section{The toxicity of A. squamosa extracts to cells}

The toxicity of $A$. squamosa leaves extracts in human colon cancer cell lines was evaluated through the measurement of LDH leakage from degraded cells. As shown in Fig. 5, the cytotoxicity significantly increased with increasing extract concentrations in both tested colon cancer cell lines. The highest concentration of $A$. squamosa extracts tested $(100 \mu \mathrm{g} / \mathrm{mL})$ was $55-58 \%$ cytotoxic to Lovo cells. Correspondingly, the cytotoxicity of $A$. squamosa leaves extracts was more apparent in HCT-116 cells; approximately $49 \%$ cytotoxicity was induced by $10 \mu \mathrm{g} / \mathrm{mL}$ of the extracts, whereas $100 \mu \mathrm{g} / \mathrm{mL}$ of the methanolic, acetonic, and aqueous extract was 74,81 , and $69 \%$ cytotoxic, respectively.

\section{The effect of A. squamosa extracts on cell migration}

To clarify the role of $A$. squamosa extracts as potential anticancer agents, their impact on the migration of cancer cells were tested. Overall, treated colon cells showed less migration after $24 \mathrm{~h}$ than untreated cells (Fig. 6). Lovo cells treated with methanol or acetone extract showed $41.8-95.8 \%$ less closure after $24 \mathrm{~h}$ than the control cells (DMSO; $p<0.005$ ), and water-extract treated cells were fully migrated. Similarly, the migration of treated HCT-116 cells was significantly lower than the control cells, with $45-49 \%$ less migration observed $(p<0.005)$.

\section{The effect of $A$. squamosa extracts on bacterial growth}

The antibacterial activity of the different A. squamosa extracts was evaluated through the measurement of the diameter of the inhibition zones surrounding the wells after incubation for $24 \mathrm{~h}$ incubation with gram-positive (B. subtilis, S. aureus, and E. faecalis) and gram-negative bacteria ( $E$. coli, $P$. aeruginosa, K. pneumoniae, and LT2). As shown in Table 3, the acetone extract displayed antibacterial activity against both gram-positive and gram-negative bacterial strains, except $S$. aureus. However, the methanolic extract inhibited the growth of all the tested bacteria. Moreover, it was the only extract with marked antibacterial activity against $S$. aureus (zone of inhibition $=16.5 \pm 0.5 \mathrm{~mm}$ ), and it was more efficient than the standard antibiotic, tetracycline (zone of inhibition $=14.8 \pm 04 \mathrm{~mm}$ ). The water extract was more sensitive to gram-negative bacteria than grampositive bacteria, with a moderate antibacterial effect observed only against $E$. faecalis $(9.5 \pm 0.5 \mathrm{~mm})$. Acetonic extract exhibited 1.3 fold higher antibacterial activity against $P$. aeruginosa than the standard antibiotic.

\section{Discussion}

Plants with a long history of use in traditional medicine represent a vast resource for the discovery and investigation of new remedies by pharmaceutical sciences $[5,30]$. For example, $A$. squamosa has been used extensively in traditional medicine in India, China, and Middle Eastern

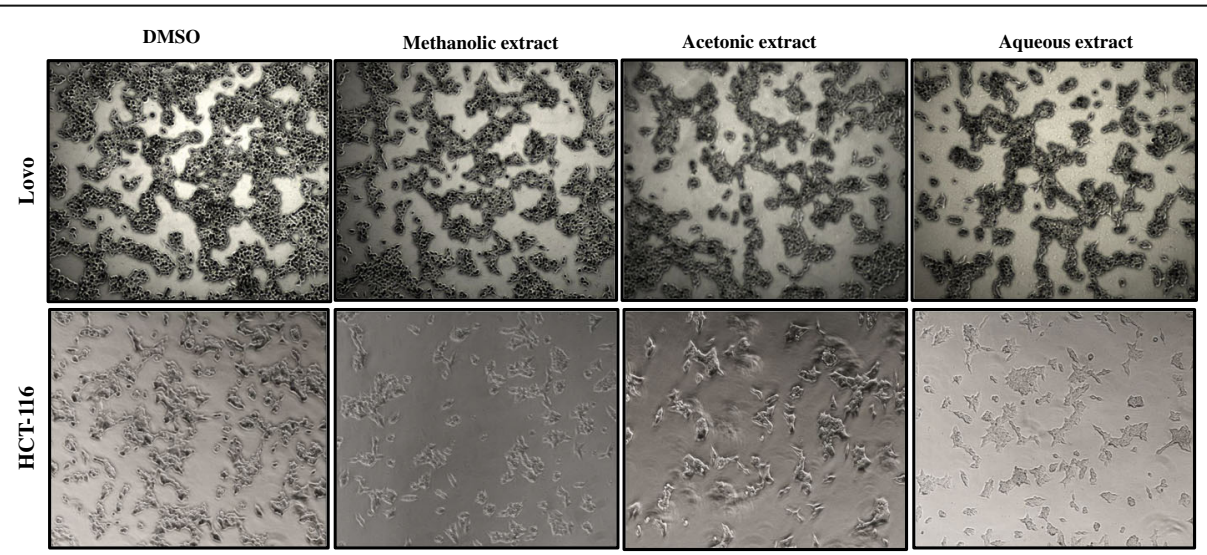

Fig. 3 The effect of A. squamosa extracts on the morphology of colon cancer cell lines. Lovo and HCT-116 cells were seeded at $4 \times 10^{5}$ and stimulated with $50 \mu \mathrm{g} / \mathrm{ml}$ methanol, acetone or water extract in DMEM medium with 10\% FBS. Photomicrographs were taken at $24 \mathrm{~h}$ 

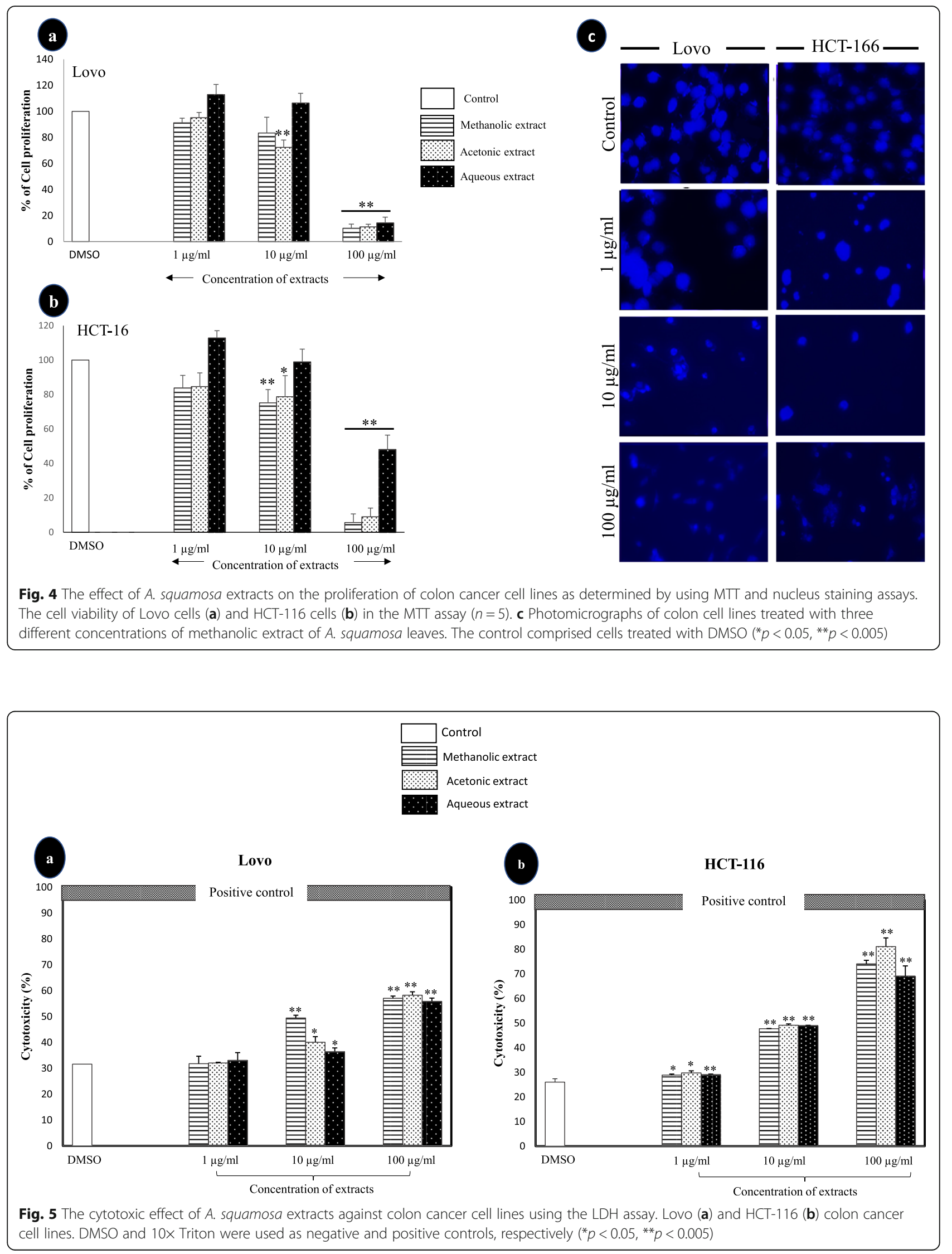


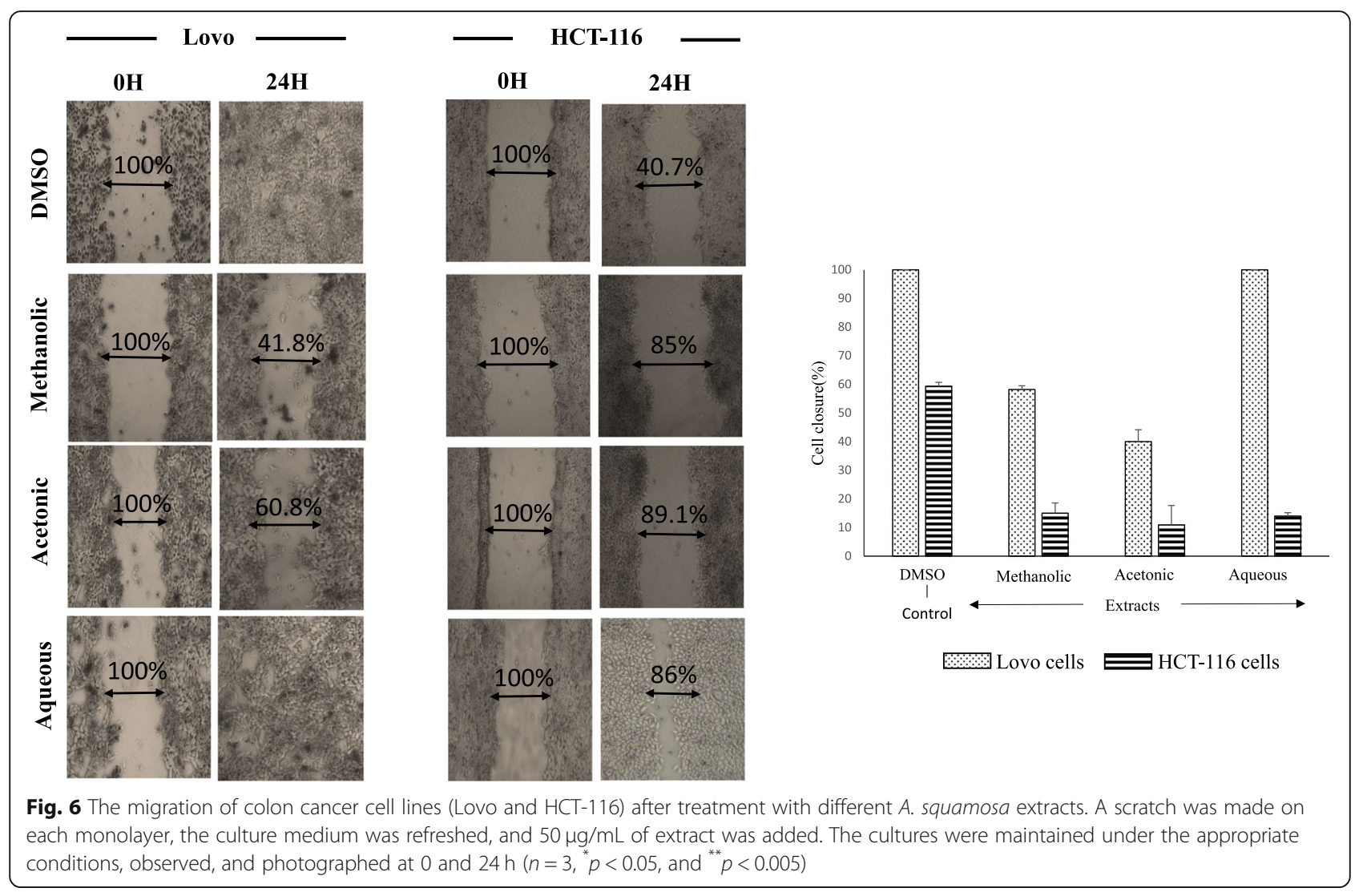

countries, but the chemical and pharmacological characterization lies behind other species from the same genus, such as $A$. muricata and $A$. reticulata. Several studies have reported the biological activities of different A. squamosa parts; fewer have investigated the leaves [18]. The purpose of the current study was to explore the biological activities of A. squamosa leaves and examine their use as potential complementary medicine or new remedies to treat diseases, especially cancer.

In phytoscience, one of the most critical challenges faced by researchers is that a single plant contains many bioactive compounds [31]. The identification of the bioactive compounds and their biological activities will help elucidate the toxicity and side effects, calculate the appropriate dosages, and find the best method to extract them. As the successful prediction of botanical compounds from plant material is mostly dependent on the type of solvent used in the extraction procedure [32, 33], three different solvents were used for extraction in this study, and the water extract was found to have the highest yield (Table 1). Thirteen compounds were identified using GC-MS in the methanolic extract of $A$. squamosa leaves. The major compounds were germacrene$\mathrm{D}$ and trans-caryophyllene, which were found to exert different biological activities in a literature review (Fig. 1): for example, germacrene- $\mathrm{D}$ was reported to induce antibacterial [34, 35], antioxidant [36], and anticancer activities [36-38]; trans-caryophyllene was shown to exhibit anti-inflammatory [39] and antibacterial activities [40, 41].

Table 3 Antimicrobial activity of A. squamosa extracts. Data are represented as mean of inhibition zone \pm SD $(n=3)$; DMSO and Tetracycline $(30 \mu \mathrm{g})$ were used negative and positive controls, respectively

\begin{tabular}{|c|c|c|c|c|c|c|c|}
\hline \multirow[t]{3}{*}{ Extracts } & \multicolumn{7}{|c|}{ Zone of inhibition (mm) } \\
\hline & \multicolumn{3}{|c|}{ Gram positive bacteria } & \multicolumn{4}{|c|}{ Gram negative bacteria } \\
\hline & B. subtilis & S. aureus & E. faecalis & $\overline{\text { E. coli }}$ & P. aeruginosa & K. pneumoniae & LT2 \\
\hline Acetone & $11.5 \pm 0.5$ & 0.0 & $8 \pm 0$ & $12.6 \pm 0.6$ & $24.6 \pm 0.6$ & $11.7 \pm 0.6$ & $11.5 \pm 0.5$ \\
\hline Methanol & $15.6 \pm 0.6$ & $16.5 \pm 0.5$ & $7.9 \pm 0.1$ & $15.5 \pm 0.5$ & $18.3 \pm 0.6$ & $11.7 \pm 0.6$ & $12.3 \pm 1.5$ \\
\hline Water & 0.0 & 0.0 & $9.5 \pm 0.5$ & $11.6 \pm 0.5$ & $17 \pm 1$ & $10.5 \pm 0.5$ & $12.2 \pm 0.3$ \\
\hline DMSO & 0.0 & 0.0 & 0.0 & 0.0 & 0.0 & 0.0 & 0.0 \\
\hline Tetracycline & $16.2 \pm 0.8$ & $14.8 \pm 0.4$ & $12.7 \pm 0.4$ & $19.3 \pm 1.5$ & $18.7 \pm 0.6$ & $18.5 \pm 0.4$ & $14.3 \pm 0.3$ \\
\hline
\end{tabular}


OS has been suggested as the root cause of several pathophysiological conditions, including cancer and inflammation $[42,43]$. As reported in many studies, several bioactive compounds from plants have shown antioxidant and radical scavenging activity, and a relationship between the antioxidant activity and phenolic content has been reported $[44,45]$. In this study, the antioxidant potential of different extracts of $A$. squamosa leaves was determined through the measurement of the scavenging activity and reducing power of RONS (Fig. 2). The DPPH free radical scavenging model demonstrated that acetone extracts displayed the highest scavenging activity, followed by methanol and water extracts (Table 1). Surprisingly, water extracts showed higher $\mathrm{H}_{2} \mathrm{O}_{2}$-scavenging activity than ascorbic acid, followed by the moderate scavenging activity of acetone and methanol extracts; this result agreed with El-Chaghaby et al. [46] (Table 1). Besides, the methanolic extract of $A$. squamosa leaves exhibited good NOscavenging ability. The overall results agreed with those obtained by Kalidindi et al. [47] and Shirwaikar et al. [48] who investigated the ability of the ethanol, methanol, chloroform, and aqueous extracts of $A$. squamosa leaves to scavenge DPPH, NO, and $\mathrm{H}_{2} \mathrm{O}_{2}$. Several studies revealed correlations between the antioxidant activity and the reducing power of some plant extract $[49,50]$. Our findings showed that $A$. squamosa leaves extracts possessed a high reducing power. Interestingly, the methanolic extract exhibited higher reducing power than ascorbic acid and BHT, which were used as reference materials (Fig. 2-d). These results were consistent with previous data reported by Kalidindi et al. [47] and El-Chaghaby et al. [46]. However, the methanolic extract displayed the highest reducing power in both previous studies but was still lower than the standards. This may be as a result of the use of heat in the different extraction methods, which was avoided in our study. Indeed, several studies suggested that heat can affect the stability of various bioactive compounds in plants, especially the flavonoids and phenols, which are strongly correlated with antioxidant activity $[51,52]$.

In recent decades, as the limitations of cancer treatment strategies have been discovered, researchers have attempted to identify natural products capable of selectively modulating different mechanisms, targeting multiple pathways involved in cancer, and increasing patient survival. However, few studies have investigated the activity of $A$. squamosa extracts as an anticancer agent. In the current study, the anticancer activities of $A$. squamosa leaves extracts were investigated in two colon cancer cell lines, Lovo and HCT-116. Our results revealed that different $A$. squamosa leaves extracts induced cytotoxicity and inhibited the proliferation of both selected cancer cell lines in a dose-dependent manner (Fig. 4). The antiproliferative activity and cytotoxicity of $A$. squamosa leaves extracts were confirmed by nuclear staining, which indicated damaged nuclei (Fig. 4-c). This result suggested that A. squamosa leaves extracts inhibited cancer cell proliferation through the induction of apoptosis via caspase-3 activation and cell cycle arrest. Several studies have demonstrated that, in general, plant extracts inhibit cell proliferation by triggering a series of signaling pathways via the phosphorylation of cell cycle proteins, such as MAPK, p53, and EGFR phosphorylation [53, 54]. Indeed, cancer cells' ability to metastasis and invasion is one of the hallmarks of cancer, and it is considered the leading cause of death among cancer patients [55]. Furthermore, previous studies have shown that Lovo and HCT-116 were highly metastatic $[56,57]$. Our results provided the first demonstration that the methanolic or acetonic extracts could partially inhibit cell migration. It is of note that no previous study has investigated the anti-migration activity of any part of the A. squamosa plant. However, Zorofchian Moghadamtousi et al. [57] demonstrated that the ethyl acetate extract of $A$. muricata leaves conspicuously blocked the migration of HCT-116 cells, suggesting the similar chemical composition of the leaves of both species (A. muricata and A. squamosa). A more recent study by Pinto [58] investigated the effects of A. squamosa seeds and leaves extracts on different tumor and non-tumor cells' ability to form colonies. The authors reported that both extracts ultimately reduced the colonogenic survival of MCF-7 and HCT-116 cells, while both extracts showed lower activity against non-tumor cells (VERO). This remarkable anticancer activity may due to the high level of germacrene-D which exerted anticancer activity against different cell lines [36-38], or to the presence of other bioactive compounds which have also been known to have an anticancer activity such as humulene, phytol and/or a combination of these bioactive compounds $[59,60]$. Collectively, these findings may assist the future development of novel drugs for colon cancer therapy.

The studies of gut microbiota in normal and pathogenic conditions have demonstrated an association between dysbiosis and human colorectal cancer. Different parts of $A$. squamosa have been used as antimicrobial agents in traditional medicine. The current study demonstrated that different extracts of $A$. squamosa leaves exhibited a broad spectrum of antibacterial activity against both grampositive and gram-negative bacteria (Table 3). The potent antibacterial activity of $A$. squamosa leaves extracts was recorded against $P$. aeruginosa, a resistant gram-negative bacterial strain. Similarly, Kotkar et al. [61] found that flavonoids isolated from the aqueous extract of $A$. squamosa exerted antibacterial activity against Pseudomonas, Bacillus, and Aspergillus species. Interestingly, A. squamosa leaves extract displayed higher antibacterial activity against the human pathogenic $S$. aureus strain than antibiotics. Indeed, infections caused by $S$. aureus have reached epidemic proportions globally owing to its strong multiresistance [62]. These results were consistent with those 
of Pinto et al. [58] who found the significant antibacterial activity of the methanolic extract of $A$. squamosa leaves and seeds against $S$. aureus, K. pneumoniae, and E. faecalis strains. Vijayalakshmi and Nithiya evaluated the antibacterial activity of $A$. squamosa fruit extracts, which exhibited more potent activity against gram-negative bacteria than gram-positive bacteria. This result could be attributed to several bioactive compounds known to have an antibacterial activity such as benzoquinoline alkaloid, annoquinone, $\beta$ bourbonene, trans-Caryophyllene, bicyclogermacrene, Palmitone and germacrene-D [19, 40, 63].

\section{Conclusion}

In conclusion, his study attempted to elucidate the ethnopharmacological uses of $A$. squamosa leaves and determine some of the main bioactive compounds which might be responsible for these biological activities. A. squamosa leaves extracts may contribute to the development of new remedies as an alternative source of antibiotics or for colon cancer therapies. Further studies are necessary to determine the molecular mechanisms which are targeting by $A$. squamosa leaves extracts.

\section{Abbreviations}

RONS: Reactive oxygen and nitrogen species; TPC: Total phenolic content; TFC: Total flavonoid content; GC-MS: Gas chromatography coupled with mass spectrometry; DPPH: 2,2-diphenyl-1-picrylhydrazyl; DMSO: Dimethyl sulfoxide; $\mathrm{NO}$ : Nitric oxide; $\mathrm{H}_{2} \mathrm{O}_{2}$ : Hydrogen peroxide

\section{Acknowledgments}

The project was financially supported by King Saud University through the Vice Deanship of Research Chairs.

\section{Authors' contributions}

All authors have read and agree to the published version of the manuscript. Conceptualization and supervision, A.A. and A.B.B.; conduct the experiment, data curation, and writing, R.A.; Chemical investigation, A.Y.B. and M.l.; Helping with the molecular investigations, A.S.; writing — review and editing, A.B.B.

\section{Funding}

This research did not receive any specific grant from funding agencies in the public, commercial, or not-for-profit sectors.

\section{Availability of data and materials}

The datasets used and/or analyzed during the current study are available from the corresponding author on reasonable request.

\section{Ethics approval and consent to participate}

Not applicable.

\section{Consent for publication}

Not applicable.

\section{Competing interests}

The authors declare no conflict of interest.

\section{Author details}

${ }^{1}$ Protein Research Chair, Department of Biochemistry, College of Science, King Saud University, Riyadh, Kingdom of Saudi Arabia. ${ }^{2}$ Groupe de Recherche en Écologie Buccale, Faculté de Médecine Dentaire, Université Laval, Québec, Canada. ${ }^{3}$ Advanced Materials Research Chair, Department of Chemistry, College of Science, King Saud University, Riyadh, Kingdom of Saudi Arabia. ${ }^{4}$ Department of Biochemistry, College of Science, King Saud University, Riyadh, Kingdom of Saudi Arabia. ${ }^{5}$ Laboratory of Plant
Biotechnology Applied to Crop Improvement, Faculty of Science of Sfax, University of Sfax, Sfax, Tunisia.

Received: 25 February 2020 Accepted: 16 July 2020

Published online: 06 October 2020

\section{References}

1. Rahal A, Kumar A, Singh V, Yadav B, Tiwari R, Chakraborty S, et al. Oxidative stress, prooxidants, and antioxidants: the interplay. Biomed res Int [internet]. 2014;2014:761264. Available from: https://www.ncbi.nlm.nih.gov/ pubmed/24587990.

2. Sosa V, Moline T, Somoza R, Paciucci R, Kondoh H, ME LL. Oxidative stress and cancer: an overview. Ageing res rev [internet]. 2013;12(1):376-90. Available from: https://www.ncbi.nlm.nih.gov/pubmed/23123177.

3. Charles DJ. Antioxidant properties of spices, herbs and other sources. New York: Springer; 2012. 589 p

4. Hussain T, Tan B, Yin Y, Blachier F, Tossou MCB, Rahu N. Oxidative Stress and Inflammation: What Polyphenols Can Do for Us? Oxid Med Cell Longev [Internet]. 2016;2016:9. Available from: https://doi.org/10.1155/2016/7432797.

5. Tundis R, Xiao J, Loizzo MR. Annona species (Annonaceae): a rich source of potential antitumor agents? Ann N Y Acad Sci [internet]. 2017;1398(1):30-6. Available from: https://www.ncbi.nlm.nih.gov/pubmed/28415154.

6. Jemal A, Bray F, Center MM, Ferlay J, Ward E, Forman D. Global cancer statistics. CA Cancer J Clin [internet]. 2011;61(2):69-90. Available from: https://www.ncbi.nlm.nih.gov/pubmed/21296855.

7. Agostinis P, Berg K, Cengel KA, Foster TH, Girotti AW, Gollnick SO, et al. Photodynamic therapy of cancer: an update. CA Cancer J Clin [internet]. 2011;61(4):250-81. Available from: https://www.ncbi.nlm.nih.gov/ pubmed/21617154.

8. Maya S, Sabitha M, Nair SV, Jayakumar R. Phytomedicine-Loaded Polymeric Nanomedicines: Potential Cancer Therapeutics. In: Dutta PK, Dutta J, editors. Multifaceted Development and Application of Biopolymers for Biology, Biomedicine and Nanotechnology [Internet]. Berlin, Heidelberg: Springer Berlin Heidelberg; 2013. p. 203-39. Available from. https://doi.org/10.1007/ 122012195.

9. Wang H, Khor TO, Shu L, Su Z, Fuentes F, Lee J-H, et al. Plants against Cancer: a review on natural phytochemicals in preventing and treating cancers and their Druggability. Anticancer Agents Med Chem [Internet]. 2012;12(10):1281-305 Available from: http://www.ncbi.nlm.nih.gov/pmc/ articles/PMC4017674/.

10. Lu WI, Lu DP. Impact of chinese herbal medicine on american society and health care system: perspective and concern. Evid based complement Altern med [internet]. 2014;2014:251891. Available from: https://www.ncbi. nlm.nih.gov/pubmed/24719641.

11. Deshmukh AB, Patel JK. Aqueous extract of Annona squamosa (L.) ameliorates renal failure induced by $5 / 6$ nephrectomy in rat. Indian J Pharmacol [internet]. 2011;43(6):718-21. Available from: https://www.ncbi. nlm.nih.gov/pubmed/22144782.

12. Dholvitayakhun A, Trachoo N, Narkkong N, Cushnie TPT. Using scanning and transmission electron microscopy to investigate the antibacterial mechanism of action of the medicinal plant Annona squamosa Linn. J Herb Med [Internet]. 2017;7:31-6 Available from: http://www.sciencedirect.com/ science/article/pii/S221080331630080X.

13. Balouiri M, Sadiki M, Ibnsouda SK. Methods for in vitro evaluating antimicrobial activity: a review. J Pharm Anal [Internet]. 2016;6(2):71-9 Available from: http://www.sciencedirect.com/science/article/pii/\$20951 77915300150

14. Davies J, Davies D. Origins and evolution of antibiotic resistance. Microbiol Mol biol rev [internet]. 2010;74(3):417-33. Available from: https://www.ncbi. nlm.nih.gov/pubmed/20805405.

15. Mwitari PG, Ayeka PA, Ondicho J, Matu EN, Bii CC. Antimicrobial activity and probable mechanisms of action of medicinal plants of Kenya: Withania somnifera, Warbugia ugandensis, Prunus africana and Plectrunthus barbatus. PLoS one [internet]. 2013;8(6):e65619. Available from: https://www.ncbi.nlm. nih.gov/pubmed/23785437.

16. Bonifacio B V, dos Santos Ramos MA, da Silva PB, Bauab TM. Antimicrobial activity of natural products against helicobacter pylori: a review. Ann Clin Microbiol Antimicrob [internet]. 2014;13:54. Available from: https://www. ncbi.nlm.nih.gov/pubmed/25406585.

17. Alkhawalidy ASR, Hossain MA. Study on total phenolics and antioxidant activity of leaves crude extracts of Annona squamosa traditionally used for 
the treatment of cancerous tumours. Asian Pacific J Trop Dis [Internet]. 2015;5(Supplement 1):142-4. Available from: http://www.sciencedirect.com/ science/article/pii/S2222180815608763.

18. Ma C, Chen Y, Chen J, Li X, Chen Y. A review on Annona squamosa L.: phytochemicals and biological activities. Am J Chin med [internet]. 2017;45(5): 933-64. Available from: https://www.ncbi.nlm.nih.gov/pubmed/28659034.

19. Nugraha SA, Damayanti DY, Wangchuk P, Keller AP. Anti-Infective and AntiCancer Properties of the Annona Species: Their Ethnomedicinal Uses, Alkaloid Diversity, and Pharmacological Activities. Molecules. 2019;24.

20. Singleton VL, Rossi JA. Colorimetry of Total Phenolics with Phosophmolybdic-Phosphotungstic acid reagents. Am J Enol Vitic. 1965;16: $144-58$.

21. Loganayaki N, Siddhuraju P, Manian S. Antioxidant activity and free radical scavenging capacity of phenolic extracts from Helicteres isora L. and Ceiba pentandra L. J food Sci Technol [internet]. 2013;50(4):687-95. Available from: https://www.ncbi.nlm.nih.gov/pubmed/24425970.

22. Narasimhan MK, Pavithra SK, Krishnan V, Chandrasekaran M. In vitro analysis of antioxidant, antimicrobial and Antiproliferative activity of Enteromorpha antenna, Enteromorpha linza and Gracilaria corticata extracts. Jundishapur J Nat pharm prod [internet]. 2013;8(4):151-9. Available from: https://www. ncbi.nlm.nih.gov/pubmed/24624206.

23. Ruch RJ, Cheng SJ, Klaunig JE. Prevention of cytotoxicity and inhibition of intercellular communication by antioxidant catechins isolated from Chinese green tea. Carcinogenesis. 1989;10(6):1003-8.

24. Garratt DC. The quantitative analysis of drugs. $3 \mathrm{~d}$ ed. London: Chapman \& Hall; 1964. xiii. p. 925.

25. Oyaizu M. Studies on products of browning reactions: antioxi- dative activities of products of browning reaction prepared from glucosamine. Jpn J Nutr. 1986:44(307-315)

26. Semlali A, Chakir J, Rouabhia M. Effects of whole cigarette smoke on human gingival fibroblast adhesion, growth, and migration. J Toxicol Env heal a [internet]. 2011;74(13):848-62. Available from: https://www.ncbi.nlm.nih.gov/ pubmed/21598170.

27. Semlali A, Jacques E, Koussih L, Gounni AS, Chakir J. Thymic stromal lymphopoietin-induced human asthmatic airway epithelial cell proliferation through an IL-13-dependent pathway. J Allergy Clin Immunol. 2010;125(4): 844-50.

28. Ruiz-Capillas C, Nollet LML. Flow injection analysis of food additives. Food analysis \& properties. Boca Raton: CRC Press, Taylor \& Francis Group; 2016.736 p.

29. Boora F, Chirisa E, Mukanganyama S. Evaluation of Nitrite Radical Scavenging Properties of Selected Zimbabwean Plant Extracts and Their Phytoconstituents. J Food Process. 2014;7. Available from:. https://doi.org/10, 1155/2014/918018

30. Petrovska BB. Historical review of medicinal plants' usage. Pharmacogn rev [internet]. 2012;6(11):1-5. Available from: https://www.ncbi.nlm.nih.gov/ pubmed/22654398.

31. Ahmad I, Aqil F, Owais M. Modern phytomedicine : turning medical plants into drugs. Weinheim: Wiley-VCH; 2006. p. 384

32. Efferth T, Li PC, Konkimalla VS, Kaina B. From traditional Chinese medicine to rational cancer therapy. Trends Mol med [internet]. 2007;13(8):353-61. Available from: https://www.ncbi.nlm.nih.gov/pubmed/176444331.

33. Ghazi-Moghadam K, Inancli HM, Bazazy N, Plinkert PK, Efferth T, Sertel S. Phytomedicine in otorhinolaryngology and pulmonology: clinical trials with herbal remedies. Pharm [internet]. 2012;5(8):853-74. Available from: https:// www.ncbi.nlm.nih.gov/pubmed/24280678.

34. Cardenas J, Rojas J, Rojas-Fermin L, Lucena M, Buitrago A. Essential oil composition and antibacterial activity of Monticalia greenmaniana (Asteraceae). Nat prod Commun [internet]. 2012;7(2):243-4. Available from: https://www.ncbi.nlm.nih.gov/pubmed/22474970.

35. Montanari RM, Barbosa LCA, Demuner AJ, Silva CJ, Carvalho LS, Andrade NJ. Chemical composition and antibacterial activity of essential oils from verbenaceae species: alternative sources of (E)-caryophyllene and germacrene-D. Quim Nova. 2011;34(9):1550-5.

36. Casiglia S, Bruno M, Bramucci M, Quassinti L, Lupidi G, Fiorini D, et al. Kundmannia sicula (L.) DC: a rich source of germacrene D. J Essent Oil Res. 2017;29(6):437-42. Available from. https://doi.org/10.1080/10412905.2017. 1338625.

37. Essien EE, Newby JM, Ogunwande IA, Setzer WN, Ekundayo O. Essential oil constituents, anticancer and antimicrobial activity of Ficus mucoso and Casuarina equisetifolia leaves. Am J Essent Oil Nat Prod. 2016:4(1):1-6.
38. Zarai Z, Kadri A, Ben Chobba I, Ben Mansour R, Bekir A, Mejdoub H, et al. The in-vitro evaluation of antibacterial, antifungal and cytotoxic properties of Marrubium vulgare L. essential oil grown in Tunisia. Lipids Health Dis. 2011;10(1):161. Available from. https://doi.org/10.1186/1476-511X-10-161.

39. Fernandes ES, Passos GF, Medeiros R, da Cunha FM, Ferreira J, Campos MM, et al. Anti-inflammatory effects of compounds alpha-humulene and (-)-trans-caryophyllene isolated from the essential oil of Cordia verbenacea. Eur J Pharmacol [internet]. 2007;569(3):228-36. Available from: https://www. ncbi.nlm.nih.gov/pubmed/17559833.

40. Rodrigues FF, Oliveira LG, Rodrigues FF, Saraiva ME, Almeida SC, Cabral ME, et al. Chemical composition, antibacterial and antifungal activities of essential oil from Cordia verbenacea DC leaves. Pharmacogn res [internet]. 2012;4(3): 161-5. Available from: https:/www.ncbi.nlm.nih.gov/pubmed/22923954.

41. Tabanca N, Demirci F, Ozek T, Tumen G, Baser KHC. Composition and antimicrobial activity of the essential oil of Origanum $\times$ dolichosiphon P. H. Davis. Chem Nat Compd [internet]. 2001;37(3):238-41. Available from: https://doi.org/10.1023/A:1012513922871.

42. Choudhari SK, Chaudhary M, Bagde S, Gadbail AR, Joshi V. Nitric oxide and cancer: a review. World J Surg Oncol [internet]. 2013;11:118. Available from: https://www.ncbi.nlm.nih.gov/pubmed/23718886.

43. Hannibal L. Nitric oxide homeostasis in neurodegenerative diseases. Curr Alzheimer res [internet]. 2016;13(2):135-49. Available from: https://www. ncbi.nlm.nih.gov/pubmed/26391043.

44. Gülçin I. Fe3+-Fe2+ transformation method: an important antioxidant assay. In: Armstrong D, editor. Advanced protocols in oxidative stress III [internet]. New York, NY: springer New York; 2015. p. 233-46. Available from: https://doi.org/10.1007/978-1-4939-1441-8_17.

45. Nandhakumar $\mathrm{E}$, Indumathi P. In vitro antioxidant activities of methanol and aqueous extract of Annona squamosa (L.) fruit pulp. J Acupunct Meridian stud [internet]. 2013;6(3):142-8. Available from: https://www.ncbi.nlm.nih. gov/pubmed/23787283.

46. El-Chaghaby GA, Ahmad AF, Ramis ES. Evaluation of the antioxidant and antibacterial properties of various solvents extracts of Annona squamosa $L$. leaves. Arab J Chem. 2014;7(2):227-33.

47. Kalidindi N, Thimmaiah NV, Jagadeesh NV, Nandeep R, Swetha S, Kalidindi B. Antifungal and antioxidant activities of organic and aqueous extracts of Annona squamosa Linn. Leaves. J Food Drug Anal. 2015;23(4):795-802.

48. Shirwaikar A, Rajendran K, Kumar CD. In vitro antioxidant studies of Annona squamosa Linn. Leaves. Indian J Exp biol [internet]. 2004;42(8):803-7. Available from: https://www.ncbi.nlm.nih.gov/pubmed/15573531.

49. Irshad M, Zafaryab M, Singh M, Rizvi MMA. Comparative Analysis of the Antioxidant Activity of Cassia fistula Extracts. Int J Med Chem. 2012;6. Available from:. https://doi.org/10.1155/2012/157125.

50. Jayanthi $P$, Lalitha P. Reducing power of the solvent extracts of Eichhornia Crassipes (Mart.) Solms. Int J Pharm Pharm Sci. 2011;3(3):126-8.

51. Lin YC, Chou CC. Effect of heat treatment on total phenolic and anthocyanin contents as well as antioxidant activity of the extract from Aspergillus awamori-fermented black soybeans, a healthy food ingredient. Int J Food Sci Nutr. 2009;60(7):627-36.

52. Ross CF, Hoye Jr. C, Fernandez-Plotka VC. Influence of heating on the polyphenolic content and antioxidant activity of grape seed flour. J food Sci [internet]. 2011;76(6):84-90. Available from: https://www.ncbinlm.nih.gov/ pubmed/22417486.

53. Ait-Mohamed O, Battisti V, Joliot V, Fritsch L, Pontis J, Medjkane S, et al. Acetonic extract of Buxus sempervirens induces cell cycle arrest, apoptosis and autophagy in breast cancer cells. PLoS One. 2011;6(9):e24537.

54. Gao JL, Shi JM, He K, Zhang QW, Li SP, Lee SM, et al. Yanhusuo extract inhibits metastasis of breast cancer cells by modulating mitogen-activated protein kinase signaling pathways. Oncol Rep. 2008;20(4):819-24.

55. Seyfried TN, Huysentruyt LC. On the origin of cancer metastasis. Crit Rev Oncog. 2013;18(1-2):43-73 Available from: https://www.ncbi.nlm.nih.gov/ pubmed/23237552.

56. Ishizu K, Sunose N, Yamazaki K, Tsuruo T, Sadahiro S, Makuuchi H, et al. Development and characterization of a model of liver metastasis using human colon cancer HCT-116 cells. Biol Pharm Bull. 2007/09/11. 2007;30(9): 1779-83.

57. Zorofchian Moghadamtousi S, Karimian H, Rouhollahi E, Paydar M, Fadaeinasab M, Abdul KH. Annona muricata leaves induce G (1) cell cycle arrest and apoptosis through mitochondria-mediated pathway in human HCT-116 and HT-29 colon cancer cells. J Ethnopharmacol. 2014; 156:277-89. 
58. Pinto NCC, Silva JB, Menegati LM, Guedes M, Marques LB, Silva TPD, et al. Cytotoxicity and bacterial membrane destabilization induced by Annona squamosa L. extracts. An Acad bras Cienc. 2017;89(3):2053-73 Available from: https://www.ncbi.nlm.nih.gov/pubmed/28813096.

59. Pejin B, Kojic V, Bogdanovic G. An insight into the cytotoxic activity of phytol at in vitro conditions. Nat Prod Res. 2014;28(22):2053-2056. Available from: https://doi.org/10.1080/14786419.2014.921686.

60. Kim CW, Lee HJ, Jung JH, Kim YH, Jung DB, Sohn EJ, et al. Activation of Caspase-9/3 and inhibition of epithelial Mesenchymal transition are critically involved in antitumor effect of Phytol in hepatocellular carcinoma cells. Phytother Res. 2015;29(7):1026-31 Available from: https://www.ncbi.nlm.nih. gov/pubmed/25892665.

61. Kotkar HM, Mendki PS, Sadan SV, Jha SR, Upasani SM, Maheshwari VL. Antimicrobial and pesticidal activity of partially purified flavonoids of Annona squamosa. Pest Manag Sci. 2002;58(1):33-7 Available from: https:// www.ncbi.nIm.nih.gov/pubmed/11838282.

62. Stefani S, Goglio A. Methicillin-resistant Staphylococcus aureus: related infections and antibiotic resistance. Int J Infect Dis. 2010;14(4):19-22 Available from: https://www.ncbi.nlm.nih.gov/pubmed/20843722.

63. Shanker KS, Kanjilal S, Rao BV, Kishore KH, Misra S, Prasad RB. Isolation and antimicrobial evaluation of isomeric hydroxy ketones in leaf cuticular waxes of Annona squamosa. Phytochem Anal. 2007;18(1):7-12 Available from: https://www.ncbi.nlm.nih.gov/pubmed/17260693.

\section{Publisher's Note}

Springer Nature remains neutral with regard to jurisdictional claims in published maps and institutional affiliations.

Ready to submit your research? Choose BMC and benefit from:

- fast, convenient online submission

- thorough peer review by experienced researchers in your field

- rapid publication on acceptance

- support for research data, including large and complex data types

- gold Open Access which fosters wider collaboration and increased citations

- maximum visibility for your research: over $100 \mathrm{M}$ website views per year

At $\mathrm{BMC}$, research is always in progress.

Learn more biomedcentral.com/submissions 